\title{
NIEUWERE OPVATTINGEN OVER GODS ALMACHT EN ZIJN ONMACHT
}

\author{
H E FABER VAN DER MEULEN
}

\begin{abstract}
New viewpoints about the omnipotence of God and his impotence

In the Bible there are no statements or definitions of the power of the Almighty God lapart from those in the book of Job). This however, does not relieve the theologian of either the necessity or the responsibility of ordering and systematising the scriptural statements about the power, or lack of power, of God. The role of the Bible in elucidating God to his children would be seriously hampered if the many instances of communication between God Almighty and man were to be overlooked, as these hold the key to our understanding of the true being of the God of the scriptures.

It is from this point of view that the article deals with the Biblical narrative of the acts of God. The opposing viewpoints of an Almighty God who provides and predestinates all, and of God as a sympathetic but impotent deity are examined. The conclusion is that God's omnipotence is manifested as a liberating force, freeing those who truly believe in Him.
\end{abstract}

\section{Inleiding}

In het Woord van God worden geen bespiegelingen over Hem gegeven. Dat wil zeggen, zelfs met een beetje goede wil is geen leer over God of een vast patroon van $\mathrm{Hem}$ in de bijbel te vinden. Abstrakte opvattingen over God komen in het Woord niet voor, hoewel iedere gelovige zijn abstrakties over God kent en zich voor zijn abstrakte visie van God op bijbelteksten beroept.

Natuurlijk moeten de bijbelse uitspraken over God worden gerangschikt en systematisch geordend, want je verstand vraagt om een begrijpelijke en logische formulering op grond van bijbelse teksten. Blijft het probleem, dat de gegevens over God in het Woord van God niet gesystem.atiseerd aan de lezer worden doorgegeven. En dit betekent, dat elke logische - en voor een mens noodzakelijke - indeling van jou zelf uit gemaakt moet worden. Beter gezegd, bijbelse opvattingen over God moeten door ons in een patroon worden samengebracht, zodat wij de woorden over God en hun bedoeling beter begrijpen en ervaren kunnen. Het gaat dan om woorden van toen, die volgens een schema van nú begrepen kunnen worden. Zo 'n patroon past bij ons en de tijd waarin wij leven. En dit betekent weer, dat het niet zeker is of een patroon samen- 
gesteld bijvoorbeeld door mense in de tijd van de middeleeuwen of in de tijd van de reformatie in onze 20 ste eeuw nog steeds voldoet. De ordening, rangschikking en indeling van bijbelse teksten over God door mensen uit vroeger tijd is mede bepaald door de vragen en problemen van hun tijd.

Heel lang heeft bij ons in de westerse kultuur de vraag naar definities en vaste formuleringen een overheersende rol gespeeld. De benadering van het leven om ons heen liep langs systematische kennis, die je verkreeg via logisch denken en experimenten. Zo leerde je waar je aan toe was. En vooral de traditie was van groot belang, want daar was de verhouding ook tussen de mens en God min of meer vastgelegd. Met behulp van een goed sluitend dogmatisch systeem kon je het juiste zicht krijgen op alle bijbelse mededelingen over God. Eenmaal "dogmatisch ontdekte waarheden" blijven en blijken altijd geldig. En jouw geloof heeft - hoe ook ervaren - uiteindelijk te maken met deze "blijvende waarheden" en het is zaak je te richten naar deze "waarheden" die in de afgelopen eeuwen via het logische denken van verstandige mensen uit de woorden van God zijn afgeleid.'

Intussen zijn andere overwegingen hierbij gekomen en nu ontstaat een botsing. Want al lang overwegen we, hoe is nu de verhouding tussen God en mij binnen zoveel definities en dogmatische waarheden? Mijn persoonlijke mening, mijn ervaring in het leven kleurt steeds mijn opvatting over wat de bijbel van God zegt en zo is het alle eeuwen geweest. Zijn algemene geloofswaarheden geen konstrukties van het menselijke verstand zonder dat Gods Woord hiervoor duidelijk aanleiding geeft? Laat het Woord van God zich wel via definities zuiver weergeven? Hangt alles in Gods Woord niet zozeer met elkaar samen, dat een definitie een woord dat "omgrenzing" betekent - niet goed mogelijk is omdat het Woord van God eerder een weefsel van gedachten en ervaringen is dan een verzameling van uitspraken over God die door ons moeten worden gerangschikt? Algemene waarheden afgeleid uit de bijbel hebben zo gauw iets ongenaakbaars, en het is net of al die zoveel omvattende geloofsuitspraken nauwelijks je hart raken. En iets wat je niet gemakkelijk op jezelf kunt betrekken, wat jou niet boeit, jou nauwelijks iets zegt, beleef je als weinig zinvol en tamelijk onwerkelijk. Algemene regels, vaste normen, standaardopvattingen over God en jouw verhouding tot Hem irriteren soms eerder dan dat ze verder helpen. Meer en meer wordt gevraagd naar het effekt van je geloofsovertuiging, naar het nut van geloven, naar de funktie ervan in het leven van alledag. Deze funktionele manier van denken dringt steeds verder en verder en dan ontstaat een botsing tussen gelovigen, die willen vasthouden aan "dogmatische waarheden" en hen die eerst het nut en de funktie van die 
"waarheden" onderzocht willen hebben. Over en weer ontstaan verwijten en de verwijdering neemt steeds meer toe, want het ordenen van Gods woorden over Hemzelf gaat op een totaal verschillende manier. Wie namelijk zoekt naar "dogmatische waarheden" vindt altijd bijbelteksten die hierbij passen en wie het nuttig effekt van al die "waarheden" betwijfelt wordt door de ervaringen van alledag in zijn mening gesterkt. De ene gelovige vindt steun, kracht en zekerheid in bestaande "dogmatische waarheden" en een medegelovige is van mening dat deze "waarheden" in Gods Woord anders bedoeld kunnen zijn.

Wie heeft gelijk? Omdat geloven heeft te maken met keuzes doen geldt ook hier, je kiest uiteindelijk voor een manier van geloven, die voor jezelf overtuigend kan zijn. lemand die rust, zekerheid en vastigheid centraal laat zijn binnen de eigen geloofsbeleving kan niet anders dan van bepaalde "dogmatische waarheden" uitgaan. Wie probeert te geloven met inschakeling van zijn kritische verstand gaat anders te werk. Omdat zo iemand zijn mondigheid niet gemakkelijk prijsgeeft noch zijn ervaring dat de werkelijkheid veelomvattender is dan een definitie of dogma ooit kan omschrijven, zal hij kritisch blijven wanneer hij probeert te geloven. $\mathrm{Hij}$ zal dus op zoek gaan, stap voor stap verder op een weg zonder veel "waarheden" vooraf en in de hoop geheel of gedeeltelijk "waarheid" te vinden. ${ }^{2}$

Wie heeft gelijk? De vraag naar het gelijk is onoplosbaar. Wel is het mogelijk je af te vragen: welke manier van geloven staat nu het dichtst bij de sfeer van de woorden van God? En dan kun je er niet om heen vast te stellen, dat - omdat het Woord van God niet de Dogmatiek van God is - het zoeken van teksten die passen bij algemeen gangbare en altijd geldende geloofswaarheden wel begrijpelijk is, wel eeuwenlang volgehouden is, maar toch niet in de bijbelse lijn ligt. Het Woord van God kent geen abstrakties en geen Godsleer, maar verhalen, psalmen, profetische uitspraken, evangeliebeschrijvingen en brieven over de ontmoeting van mense met God en met elkaar. Wil je hier ordenen - en zonder een zekere systematisering gaat het niet voor een mens - mag die ordening niet worden opgelegd aan de woorden van God, die keer op keer zo nauw met elkaar verweven zijn, dat een duidelijke definitie hier gauw te ver gaat. Dat wil zeggen, een duidelijke definitie doet gauw tekort aan het geheel van het Woord van God. Want steeds weer zullen Gods woorden elk patroon doorbreken. Dit doorbreken van elke systematisering is natuurlijk heel begrijpelijk omdat het gaat om de mens en God, die de Ander is. En deze Ander overstijgt elke systematische indeling van onze kant, zodat een zeker logisch patroon alleen als hulpje om te geloven kan dienen, maar nooit als centrum van het geloof. De Ander laat zich uiteindelijk in geen enkele "dogmatische waarheid" her- 
kennen, zodat je altijd gemakkelijk verglijdt in een systematisering die aan de bijbel wordt opgelegd. Op zich is dit niet helemaal te vermijden, maar de rust, zekerheid en vastigheid die velen uit geloofsformuleringen putten liggen niet in het verlengde van de woorden van God. Integendeel, het Woord van God is vol van verhalen die op een veelkleurige manier vertellen van mensen en hun omgang met God. Een systematisering die deze bijbelse veelkleurigheid - al dan niet met opzet probeert buiten te sluiten ondermijnt de bedoeling van het Woord van God.

\section{God in beweging}

Omdat het Woord van God bestaat uit een beschrijving van menselijke ervaringen met Hem die onderling steeds weer even verschillen, is het misschien goed één zo ' $n$ beschrijving als uitgangspunt te nemen.

Volgens de bijbel ontmoeten God en de mens elkaar steeds weer, want God zoekt keer op keer kontakt met mensen. In het tweede boek van de Tenach maakt God zich bekend aan een onzekere Mozes (Ex 3 en 4). Het bijzondere in deze beschrijving van de ontmoeting tussen God en Mozes is het feit, dat hier door een mens aan God wordt gevraagd wie $\mathrm{Hij}$ in feite is, dat wil zeggen wat een mens aan God heeft. Uit de reaktie op die vraag kan veel duidelijk worden over de manier, waarop God zich bezig houdt met de wereld van de mens en de mens zich betrokken voelt op Hem.

Om te beginnen laat God weten: Ik heb gezien hoe ellendig mijn volk eraan toe is ... Ik heb gehoord hoe ze schreeuwen om verlost te worden ... Ik weet hoeveel ze moeten doormaken. Daarom ben Ik op weg gegaan om hen te bevrijden ... en te brengen naar een land dat overvloeit van melk en honing (Ex 3:16 en 17).

Dit is de reaktie van Gods kant op de aarzelingen van Mozes als hij de opdracht krijgt om het volk naar het beloofde land te brengen, want als hij aarzelt en probeert aan zijn opdracht te ontkomen reageert God met de opmerking: ... maar lk ben toch bij je. Echter dan volgt de vraag, als de israelieten willen weten wie die God is, die via Mozes tot hen spreekt en laat horen, dat Hij hen wil bevrijden, wat moet Mozes dan zeggen? Hoe heet God?

Ik ben, die Ik ben antwoordt God. En in het vervolg van het verhaal van hoofdstuk 3 en 4 van het boek Exodus speelt deze omschrijving van God een bepalende rol. Hij ziet, hoort en weet wat het volk Israel overkomt en daarom is $\mathrm{Hij}$ op weggegaan om te bevrijden en te brengen naar een goed land. God houdt zich bezig met de bevrijding van zijn volk en Hij legt een relatie, zoekt kontakt, is in beweging naar 
zijn volk toe. In deze samenhang betekent de op zich niet duidelijke omschrijving Ik ben, die Ik ben zoveel als Ik-ben-er-bij-aanwezig, zoalsIk-er-bij-aanwezig-ben. Het gaat hier om een zogenoemde idem per idem konstruktie, die vaker voorkomt in de Tenach. Deze kan worden gebruikt om een indefinitum aan te geven. En ook wil de tijd waarin deze hebreeuwse konstruktie staat een handeling tot uitdrukking brengen, iets wat steeds maar bezig is. ${ }^{3}$ Want God heeft gezien, gehoord en geweten en daarom zet $\mathrm{Hij}$ zich in beweging.

Tegelijk ligt in de omschrijving Ik ben, die Ik ben iets vreemds, iets afstandelijks. Het is zoals de vroegjoodse schrijver Philo zegt in zijn parafrase van dit verhaal: en God antwoorde: Om te beginnen zeg hen ( = de israelieten), dat Ik de zijnde ben, zodat zij, wanneer zij het verschil leren kennen tussen het zijnde en het nietzijnde ook er van doordrongen raken, dat er voor $\mathrm{Mij}$, aan wie alleen het zijn toekomt, geen enkele mijn wezen treffende naam bestaat (Vita Mos.I.75).

Deze omschrijving herinnert aan andere woorden van God in hetzelfde boek Exodus (33:19): ... Ik zal medelijden hebben met wie Ik wil en Ik zal mild zijn voor wie lk wil. In dit verhaal over een andere ontmoeting met God gaat het om de vraag van Mozes of hij God zou mogen zien. De reaktie is: alleen in het voorbijgaan zal Mozes God kunnen zien en dan op die manier, dat hij een glimp van Gods achterkant ziet. Dus ook deze keer gaat God in op een verzoek van Mozes, maar ook deze keer blijft er een afstand.

Om die reden vertaalt Houtman in zijn recente kommentaar op Exodus de uitdrukking Ik ben, die Ik ben als "Ik ben wie Ik ook maar ben" en dan als "wat doet het er toe wie Ik ben." 4 Bij deze vertaling ontwijkt God de vraag van Mozes. Het vragen naar de naam heeft geen zin, want die gaat het menselijke verstand te boven. Deze uitleg ligt in de lijn van een verhaal uit Richteren (13). Wanneer Manoach van de engel de belofte krijgt dat zijn vrouw zwanger zal worden en een zoon zal krijgen - Simson - die het volk Israel zal verlossen van de filistijnen vraagt hij: hoe is uw naam. Dan weten mijn vrouw en ik wie we dankbaar moeten zijn, als uitkomt wat $u$ hebt beloofd. Maar dan reageert de engel heel afwijzend en zegt: Waarom willen jullie weten hoe ik heet, dat heeft geen zin, want het gaat jullie verstand toch te boven (13:17 en 18).

Hier wil de engel dus niet, dat de kennis van de naam leidt tot verering dat wil zeggen hij wil de naam niet uit handen geven voor verering. Het kennen van de naam betekent niet het in bezit hebben van de drager van de naam, dat wil zeggen: het kennen van de naam zou kunnen betekenen, dat het anderszijn van de drager van de naam niet voldoende 
erkend wordt. ${ }^{5}$

Maar in het verhaal van Exodus ligt het toch wat anders. Want nadat God zich met de naam Ik ben, die Ik ben heeft genoemd gaat $\mathrm{Hij}$ door en zegt dat Mozes de israelieten moet laten weten: Ik-ben-er heeft mij gestuurd (3:14). En daarna volgen de bewogen zinnen van Gods kant, dat Hij heeft gezien, gehoord en geweten en daarom op weg is gegaan om te bevrijden en te voeren naar een goed land.

Vanuit deze samenhang is toch duidelijk, dat de uitdrukking Ik ben, die Ik ben zowel nabijheid als afstand betekent, terwijl ook een beweging mede een rol speelt. Ik ben, die Ik ben ... Ik ben bezig, zoals Ik bezig ben ... Ik ben erbij, zoals Ik er bij ben ... Ik ben aanwezig, zoals Ik aanwezig ben. Maar dan kan de vertaling het beste luiden Ik ben er bij, op mijn manier.

Deze vertaling heeft het grote voordeel, dat de kloof tussen God en mens niet daarin ligt dat God zich niet aan mensen bekend zou willen maken. Integendeel God blijkt om mensen bewogen en daarom kan $\mathrm{Hij}$ van zichzelf zeggen: Ik ben bij hen, op mijn manier. Want het is de mens niet gegeven de Ander op een juiste manier kompleet te beschrijven en te begrijpen. De Ander overstijgt volkomen ons voorstellingsvermogen, maar die Ander wil bij mensen zijn. Omdat Hij ziet, hoort en weet hoe het met hen misgaat, zet Hij zich in beweging en is op zijn manier bij hen aanwezig. Vanuit God gezien is er wel een kloof tussen Hem en de mensen maar geen afstand.

Als Mozes eerst aan God vraagt naar zijn naam en later om zijn zichtbare aanwezigheid zit hier de gedachte achter, dat een mens vraagt naar het funktioneren van God. In het oude en nieuwe testament wordt regelmatig herinnerd aan wat Hij doet, zonder dat globale, abstrakte formuleringen worden gebruikt om een leer van God op te stellen. Gods Woord gaat eerder uit van het doen van God dan van het zijn van Hem. In een joods kommentaar op de omschrijving Ik ben, die lk ben volgt als verklaring: lk word genoemd naar mijn daden. ${ }^{6}$

Vanuit de bijbel gezien gaat het voor een mens die God wil kennen om het volgende: te proberen de beweeglijkheid van God te volgen. Een beweeglijkheid die steeds weer draait om de mens, maar die de mens niet helemaal begrijpen of bevatten kan. En hierbij past dan ook, dat wie God wil leren kennen en in overeenstemming met Gods bedoeling wil leven in deze beweeglijkheid wordt binnengevoerd. En zo wordt het begrijpelijk, dat Jeremia een keer God sprekend kan invoeren met zijn mening over iemand, die Hem wilde kennen en leven volgens Gods bedoeling: ... deze mens kwam op voor armen en weerlozen; dat noem Ik: Mij kennen. Zo spreekt de Heer (22:16).

Voor ieder die probeert te geloven is duidelijk dat er bepaalde 
geloofsvoorstellingen bestaan. Als mens en gelovige heeft iemand graag een mening over God en de funktie van zijn geloof en inderdaad ieder mens, of hij zich een gelovige noemt of niet, heeft een mening over Hem. Het Woord van God vertelt over God en de manier waarop Hij bij mensen aanwezig is. Kloppen onze gangbare meningen en gedachten over God met wat de woorden van God zeggen? Zonder een zekere logische indeling is het ondenkbaar dat de bijbelse boodschap bij lezer en luisteraar overkomt, maar welke meer bij deze tijd passende, funktionele manier van "indelen" van de woorden van God zou mogelijk zijn.

Bijvoorbeeld: God de Almachtige, wie is Hij? Wij willen nu nagaan - beinvloed door de eerder genoemde overwegingen - hoe de verhouding is tussen de almacht van God en de enorme macht van het kwaad. Het gaat dan eerst om de vraag: wat heb ik, als gelovige, aan mijn geloof in Gods almacht wanneer het kwaad mij treft? Vervolgens wordt vanuit velerlei ervaringen van alledag de vraag overwogen: is het niet beter eerder van Gods onmacht dan van zijn almacht te spreken? Aansluitend aan deze overwegingen volgt de vraag: is vanuit Gods Woord af te leiden, dat God macht over het kwaad heeft en om wat voor macht gaat het dan?'

\section{God als Almachtige}

In het hebreeuwse Oude Testament wordt God nooit de Almachtige genoemd. In het Nieuwe Testament komt deze omschrijving tienmaal voor. Negenmaal wordt God zo genoemd in de Apokalypse van Johannes. ${ }^{8}$ Het gaat hier om visioenen die in beeldspraak weergeven wat het einde van de tijd voor de mensheid zal betekenen. In bijna schrille tegengestelde kleuren "schildert" de auteur de betekenis van het zogenaamde eindgericht voor gelovige en nietgelovige mensen.

En wanneer Paulus duidelijk in wit en zwart gelovigen en nietgelovigen van elkaar wil onderscheiden gebruikt hij ook éénmaal het griekse woord pantokrator, dat wij doorgaans met Almachtige vertalen. De achtergrond voor deze uitdrukking, die bij Paulus aan het einde van een reeks oudtestamentische teksten wordt gebruikt en in de Johannesapokalypse een duidelijke oudtestamentische kontext heeft is zeer waarschijnlijk jhwh șeba'ot. ${ }^{9}$

Maar God wordt toch veel vaker in de bijbel de Almachtige genoemd? Ja, in onze bijbelvertalingen vinden we regelmatig God als almachtig omschreven. Het hebreeuwse woord sjaddai, dat meestal zo wordt vertaald is waarschijnlijk niet te vertalen; beter gezegd: tot nu toe is nog niet overtuigend aangetoond welke vertaling hier de juiste zou zijn. Het is dan ook niet zonder reden, dat bijvoorbeeld de nieuwe verta- 
ling vanwege de Societas Hebraica Amstelodamensis van het boek Ruth geen vertaling geeft voor het woord Sjaddaj, maar het als eigennaam voor God handhaaft. ${ }^{10}$

De tienmaal dat de uitdrukking pantokrator - letterlijk "Albeheerser" - in het Nieuwe Testament wordt gebruikt gaat het om een omschrijving voor God als Macht, die bezig is de wereld te beheersen en in de samenhang met het einde vande tijd, zoals dat via visioenen in het laatste bijbelboek beschreven wordt, lezen we hoe God in een gevecht met het kwaad druk doende is de wereld te beheersen. Van Gods almacht, zoals die onder gelovigen vaak wordt opgevat, is geen sprake. Is, vanuit de bijbel gezien, een omschrijving voor God als de Almachtige in feite wel juist?

Heel gangbaar is toch, dat mensen - of ze zich gelovig noemen of niet - aan Gods overmacht denken en van Hem een voorstelling hebben als een Almachtige. Alleen een Almachtige kan toch God zijn? En in het Woord van God lezen we toch ook vaak over zijn macht die alles overtreft? Trouwens wat heb je aan een God die niet almachtig is? God is toch machtiger dan het kwaad en Hij overwint het kwaad en brengt goedheid voor de mensen? Stel dat God niet de Almachtige is, aan wie moet een gelovige zich dan toevertrouwen?

Zo leert Israel zijn God kennen als Eén, die ingrijpt ten goede. Vooral als het volk zucht onder de macht van de egyptenaren maakt Hij aan Mozes bekend, dat Hij ziet, hoort en weet hoe mensen lijden en daarom zet $\mathrm{Hij}$ zich in beweging en komt naar mensen toe om hen te bevrijden en te voeren naar een goed land. Het Exodusverhaal toont duidelijk hoe (al)machtig hun God is, in elk geval machtiger dan de goden en de farao van Egypte. In de verdere beschrijving van de geschiedenis van het volk Israel wordt verteld over moeite, leed en zorgen van de mensen, waaruit God steeds weer zijn volk redt. Dus uiteindelijk is God machtiger dan welke vijand of welke tegenslag ook, want telkens weer zet Hij zich in beweging om te redden. Dit reddend ingrijpen van God loopt uit op het Tweede Testament - want intussen is voorgesteld niet meer van Oude en Nieuwe Testament, maar van Eerste en Tweede te spreken en te schrijven $^{11}$ - dat begint met het geboorteverhaal van Jezus wiens naam God redt betekent. Zowel het Eerste als het Tweede Testament leren, dat God - hoe ook - reddend ingrijpt en op deze manier laat Hij zien wie uiteindelijk de meeste macht heeft of de Almachtige is.

Maar als Hij almachtig is, waarom heeft Hij niet ingegrepen toen miljoenen in Westeuropa gebeden hebben omdat $\mathrm{Hij}$ in de oorlog aan hun kant zou staan en miljoenen in concentratiekampen en miljoenen in andere oorlogsellende zijn almacht zo dringend nodig hadden? $\mathrm{Na}$ de eerste wereldoorlog ging een golf van ongeloof door Europa en na de 
tweede wereldoorlog vraagt elke gelovige in Europa, die wil meevoelen en meedenken, naar de almacht van zijn God toen het erop en eronder ging. En in Zuidafrika waar zoveel goedwillende mensen proberen een manier van samenleven te kreëren, waarin de veelkleurigheid van de zuidafrikaanse samenleving gelijkwaardig tot ontplooiing komt, hoeveel wordt niet gebeden tot God opdat het goede mag zegevieren, dat $\mathrm{Hij}$ in zijn almacht een gezonde en gelukkige samenleving in Zuidafrika laat ontstaan. Maar is het toch zo, dat de tegenkrachten van het kwaad machtiger is dan wij ooit hebben vermoed? Is het kwaad zelfs machtiger dan onze almachtige God, die in het verleden het zinloos lijden van miljoenen van zijn mense schijnbaar niet heeft kunnen voorkomen? Heeft het kwaad eigen machtsgebieden waar God geen invloed heeft? Kan Gods goedheid het kwaad niet keren en is Hij helemaal niet almachtig?

Het aardige van Gods Woord is vaak, dat allerlei gevoeligheden en teleurstellingen met het geloof nadrukkelijk worden besproken. Het geloof is, bijbels gezien, een geschenk van God (Eph 2:8), maar een gemakkelijk kado is het zeker niet. Zit niet in elk mens het oerstreven van zoeken naar een "goede kracht", die machtig genoeg is om alles - hoe ook - recht te zetten en het leven zinvol te laten zijn? En dus is het niet gemakkelijk aan de bijbelse korrektie op dit oerverlangen gehoor te geven en hiervoor ruimte te scheppen binnen de eigen geloofsovertuiging. Onze vraagstelling luidt dus nog steeds: wat heeft een mens nu aan zijn geloof in de macht van God als het kwaad hem treft? In het boek Job lezen we over de gelovige Job die door het kwaad getroffen wordt. Het gaat om de lijdende mens en de reakties van mensen uit zijn omgeving. Het blijkt nu, dat die "mensen uit zijn omgeving" via al dan niet logische redeneringen proberen te troosten, te begrijpen en te verwijzen naar God. Maar zoals zo vaak, bestaat er een onoverbrugbare afstand tussen de lijdende mens en "mensen uit zijn omgeving", die zelf dat lijden niet ondergaan. Terwijl zijn vrienden troostwoorden spreken en redeneringen formuleren om de lijdende Job bij te staan, hebben zij een heel stellige opvatting over God: Hem mag je niets verwijten, want als het leed en ongeluk jou treffen is dit Gods reaktie op de fouten die jij hebt gemaakt. Alleen een zware zondaar moet zo zwaar lijden als Job. En dus moet hij onderzoeken wat hij heeft misdaan en zijn zonden voor God belijden. Want God straft de zondaar en zegent degene die het goed doet.

Een dergelijke opvatting herinnert aan de profeet Ezechiel, die duidelijk een patroon van Gods handelen in de geschiedenis van zijn volk ziet. Het volk Israel zondigt telkens weer in de op elkaar volgende perioden van zijn geschiedenis en elke keer wordt God grimmiger, elke keer neemt zijn boosheid toe en dat gaat zover, dat de profeet God sprekend 
invoert met de woorden: ... en ook gaf Ik hun wetten die slecht voor hen waren en voorschriften die hun geen voorspoed brachten ( $E z$ 20:25).

Het volk heeft niet anders verdiend, onophoudelijk heeft het kwaad gedaan, voortdurend heeft God goeden voorschriften en regels gegeven om het volk in het rechte spoor te brengen en dan tenslotte kan het niet anders of eindelijk moet al dat kwaad gestraft worden en Gods goedheid keert om in zijn tegendeel. ${ }^{12}$

Maar Job leeft niet in een sfeer, waarin hij zich verstandelijk met leed kan bezighouden, want hij is door leed getroffen en hij lijdt pijn, huilt, klaagt, schreeuwt, vloekt ... en respekteert God. Dat wil zeggen in zijn verwerking van het leed, in zijn gevecht met het kwaad probeert hij te verwerken, dat God macht heeft om het kwaad te keren en hij gaat een gevecht aan met die machtige God. ${ }^{13}$

Job begint bij God zijn beklag te doen: ... laat me toch met rust ... waarom houdt $U$ mij in het vizier, ben ik $U$ soms tot last ... (7:16 en 20). Maar als het Gods wil is, wie kan daar tegenop? Wanneer God toeslaat, wie zal het beletten? ... (9:12). Ik ben onschuldig ... de schuldige samen met de onschuldige vernietigt $\mathrm{Hij}$ (9:21 en 22). Wanneer het leed je treft en je weet niet van zonden die je hebt gedaan? Wat voor zin heeft het dat $U$ mij onrecht doet ... waarom anders $z 0$ mijn zonden opsporen ... terwijl $U$ weet dat ik onschuldig ben? $(10: 3,6,7)$. Jobs woede en teleurstelling over het kwaad dat hem treft gaan verder en hij zegt: God kwelt mij ... ik ben zijn doelwit en zijn pijlen vliegen mij om de oren ... ik roep: ik word overweldigd, maar niemand hoort me; ik schreeuw om hulp, maar er bestaat geen recht meer $(6: 13 ; 19: 7)$.

Vaker weer, op een andere manier vinden we aanklachten tegen God in het Eerste Testament, gaan bijbelschrijvers een gevecht aan met God en overstelpen Hem met verwijten. In psalmen wordt God gevraagd eindelijk eens in te grijpen en iets goeds te doen voor hen, die in Hem geloven. ${ }^{14}$

De profeet Jesaja kan vragen: waarom, God, laat $U$ ons van uw wegen afdwalen? Zó sluiten wij ons van $U$ af en kunnen geen ontzag meer voor $U$ opbrengen (63:17). En de profeet Jeremia zegt heel direkt: waarom komt er geen eind aan mijn lijden? ... ik kan werkelijk niet meer op $U$ vertrouwen, God, $U$ bent voor mij net als water uit een beek die telkens droogvalt (15:18).

Op deze vrije en direkt manier kan dus een gelovige met God omgaan, want wanneer $\mathrm{Hij}$ ziet, hoort en weet hoe een mens lijden moet zet Hij zich in beweging en komt naar de lijdende toe, zodat er geen afstand is tussen God en de mens die door kwaad getroffen wordt. Maar 
tegelijkertijd is God de Ander en Hij heet Ik ben er bij, op mijn manier. Er is geen afstand, maar wel een kloof tussen God en de lijdende mens en daarom begrijpen bijvoorbeeld de profeten Jesaja en Jeremia niet hoe God werkt en hoe zijn macht als macht over alles en iedereen funktioneert. Jesaja ontdekt, dat God de slechten straft en de goeden redt, maar dat aantal goede mensen is heel klein dat vormt een rest en met die rest wil God verder gaan (Jes. 65). God geeft ieder het zijne en gaat dan op zijn eigen manier verder met zijn volk. Als antwoord op de eerder genoemde aanklacht van Jeremia laat God weten: neem je woorden terug ... dan zal Ik je weer bij Mij toelaten ... spreek waardevolle en geen overmoedige woorden ... want Ik ben bij je om jou te helpen ... Ik zal je bevrijden uit elk gevaar, je beschermen tegen elk geweld $(15: 19-21)$. En daar moeten - om zo te zeggen - zowel Jesaja als Jeremia het mee doen. God als de Ander, zet zich in beweging, helpt, bevrijdt en beschermt meer wordt niet gezegd. De belofte, dat God als de volstrekt Andere op zijn manier helpend, bevrijdend en beschermend aanwezig is wordt door Hem uitgesproken en verder komt een mens niet.

Tegenover Job beroept God zich uitvoerig op zijn anders-zijn, op het feit dat $\mathrm{Hij}$ de Ander is. Maar wat Jobs vrienden hebben gezegd klopt niet, want Hij zegt tegen Jobs vrienden: ... jullie hebben niet zo 'n zuiver beeld van Mij gegeven als mijn dienaar Job (42:7). De vrienden met hun logische redenering van Gods verhouding tot mensen, die berust op een automatisme van belonen en straffen voor goede en kwade daden, hebben het mis. Een automatisme dat van het begin aan zit in het al of niet juist handelen van de mens, want de goede daad op zich heeft een goed gevolg in zich en de kwade daad op zich heeft boze gevolgen in zich. Het is nu de.gelovige, die hoopt op God, dat Hij deze samenhang ten goede bepalen wil. En zo neemt God het op voor de lijdende Job en gaat naast de mens staan die Hem aanklaagt. Hij is aanwezig op zijn manier en een gelovige kan op Gods aanwezigheid alleen met vertrouwen reageren. Voor iemand, die probeert te blijven geloven wanneer hij lijdt, is en blijft God de Ander die voor hem onbegrijpelijk blijft maar vertrouwd mag worden. Job zegt aan het einde van zijn gesprek met God: ... alleen van horen zeggen kende ik $U$, maar nu heb ik $U$ met eigen ogen gezien $142: 5)$. Job houdt een diep vertrouwen in deze God, de zo dicht bij hem komt. En daarna zegt hij tegen God: alles herroep ik, over alles heb ik spijt (42:6).

Volgens het dramatische gedicht over Job is het dus de mens niet gegeven Gods handelen te begrijpen in die zin, dat Gods macht en zijn verhouding tot het kwaad na te trekken valt. Hij blijft de volstrekt Andere, die uiteindelijk voor een gelovige, als het kwaad hem treft, 
alleen in een sfeer van vertrouwen te benaderen is. Het gedicht over Job, die psalmgedichten en de woorden van profeten geven géén sluitende redenering over Gods macht en de macht van het kwaad. De poging om Gods macht als een vergeldende macht op te vatten in die zin, dat kwaad een mens treft als straf voor zijn daden, wordt in Gods Woord zelf al tegengesproken.

$\mathrm{Nu}$ heeft zich nog daarnaast iets later de redenering ontwikkeld, dat - hoe het ook komt - alles goed is, wat God doet. In zijn hymnische gedicht over de almacht van God schrijft Jezus ben Sira o.a.: de werken des Heren, ze zijn alle zeer goed ... de daden van alle mensen liggen voor Hem open en niets kan verborgen worden voor zijn ogen; van eeuwigheid tot eeuwigheid heeft $\mathrm{Hij}$ toegezien en niets is wonderlijk in zijn ogen ... daarom was het van meet aan mijn vaste overtuiging; ik heb erover nagedacht en stelde het op schrift: de werken des Heren zijn alle goed, en $\mathrm{Hij}$ voorziet in alle behoeften op hun tijd; men kan niet zeggen: Dit is slechter dan dat, want alles wordt op zijn tijd goed bevonden $(39: 16,19,20,32-34) .^{15}$

Intussen is het zo, dat lang niet iedereen zich tevreden kan geven met deze bijbelse opvatting over de macht van God. Noch wat de profeten zeggen, noch wat de wijsheidsleraar ben Sira heeft overdacht kan op den duur bevredigen. Jobs geloofshouding maakt wel grote indruk, maar veel gelovigen vragen zich af of er niet wat meer en nog wat anders gezegd en ervaren kan worden.

En zo is de vraag gesteld, of het niet veel beter zou zijn in plaats van de macht van God van zijn onmacht te spreken? Maakt God zich niet veeleer bekend als de onmachtige, die mensen als partners nodig heeft om Hem te helpen het kwaad te keren? Zo ontstaat als reaktie op de ons bijna verlammende almacht van God die voor alles vergelding wil en dan alles wel ten goede zal keren - maar de ervaring leert dat dit niet waar is - en verwacht, dat wij als gelovigen zijn goedheid steeds weer erkennen - maar die goedheid is niet altijd meer herkenbaar - het vermoeden, dat wij juist God moeten helpen zijn macht ten goede zich overal te laten ontplooien. En is het dan niet beter eerder van Gods onmacht dan van zijn almacht te spreken?

\section{God als de Onmachtige}

Zou het kunnen zijn, dat we beter over de onmacht van God kunnen nadenken en er vanuit gaan dat wij als mensen een min of meer helpende funktie hebben binnen Gods macht? Zijn de mensen partners van God omdat $\mathrm{Hij}_{\mathrm{ij}}$ niet in staat is alleen zijn macht in deze wereld te vestigen en 
staan we met deze opvatting het beste in de lijn van zowel Oude als Nieuwe Testament?

De opvatting, dat God niet als de Almachtige moet worden gezien maar als Één die vanuit zijn onmacht het kwaad wil bestrijden, wordt gevoed door de vaak overdreven voorstelling van gelovigen over de almacht van God. Het spreken en schrijven over Gods onmacht is deels een reaktie op de verlegenheid van gelovigen met de alles en iedereen beheersende almacht van hun God.

Is God wel in staat het kwaad te keren? Zo ja, waarom doet Hij dat dan niet als dat kwaad jou treft? Als antwoord hierop volgt de overweging, dat God net als jij overvallen kan worden door het kwaad. God is om zo te zeggen - even verstijfd van schrik en pijn als een mens die door tegenslag en ander kwaad getroffen wordt. In zijn medelijden en bezorgdheid om de lijdende mens komt Hij vlakbij jou en wil jou als slachtoffer van het kwaad helpen er mee om te gaan, helpen er door heen te komen.

God is dus niet een macht, die alles weet en van te voren al ziet aankomen, ook geen macht, die de oorsprong is van al het goede en al het slechte, dat een mens kan overkomen. Nee, God wil een gevecht aangaan tegen het kwaad samen met een mens die er door getroffen is. God kan niet voorkomen dat mensen door kwaad overrompeld worden, maar Hij kan wel door zijn aanwezigheid juist bij de lijdende mens helpen om een manier te vinden zich niet door het kwaad er onder te laten krijgen en anderen te inspireren voor hun door het kwaad getroffen medemens hulp te vinden en steun te geven.

Tegenover zo 'n immens almachtige God, die alles kan en alles doet zoals $\mathrm{Hij}$ het wil, kan een gelovige zich zo machteloos voelen en daarom wordt sinds langere tijd voorgesteld om God veeleer als onmachtig te ervaren, dat wil zeggen als een macht die niet zonder de hulp van mensen kan. De bijna verpletterende almacht van God is voor al minder gelovigen een aangename geloofservaring. Vaker zal een gelovige zich innerlijk tegen die enorme macht van God verzetten en misschien hierdoor vanuit zijn geloof nauwelijks nog kracht vinden in zijn door het kwaad bedreigde leven staande te blijven.

Als jij onder kwaad te lijden hebt en vanuit je geloof de mening hebt, dat God met behulp van zijn almacht alles zo regelt en stuurt als Hij wil, zul je op den duur minder kracht en hulp zoeken bij een God, die hoe ook - medeverantwoordelijk schijnt te zijn voor het kwaad dat jou is overkomen. Wie niet onder kwaad gebukt gaat kan makkelijker in 't algemeen over een God spreken, die alle goede en kwade ervaringen in het leven van een mens volgens zijn wil regelt, dan iemand die lijdt onder het kwaad en moet geloven, dat God het kwaad voor hem wel goed heeft 
gevonden. ${ }^{16}$

En bijbels gezien maakt God zich inderdaad ook bekend, als de Helpende die ingrijpt wanneer het mis is gegaan. Aan Mozes bijvoorbeeld laat God weten, dat Hij op weg is gegaan om het volk Israel te bevrijden van de slavernij bij de egyptenaren omdat Hij weet, ziet en hoort dat de israelieten zoveel moeten lijden. In dit belangrijke gesprek van God met Mozes (Ex 3) wordt er vanuit gegaan, dat kwaad aanwezig is in het leven van het volk Israel en omdat het kwaad zo ondragelijk wordt komt God om zijn volk bij te staan en zo wordt Mozes geinspireerd de leider van de israelieten te worden bij hun uittocht uit Egypte. Mozes voert geen diskussie met God over de vraag of $\mathrm{Hij}$ al die ellende van zijn volk niet had kunnen voorkomen, zelfs vraagt Mozes niet waarom de israelieten zo moeten lijden. Hier is een duidelijk verschil met bijvoorbeeld een bijbelse figuur als Job die God aanklaagt en profeten en psalmdichters die Hem allerlei verwijten maken omdat het kwaad zoveel ruimte inneemt in hun leven.

Is God voor jou niet meer de Almachtige die alles en iedereen be heerst, zal Hij ook niet de macht zijn die het kwaad gebruikt om jou te straffen of door de ervaring van het lijden van binnen zuiverder te maken of door het sturen van leed na te gaan of jouw geloof onder de druk van narigheid wel intakt blijft. Dus God stuurt jou het kwaad niet en God heeft niet op een keer geprogrammeerd: dan en dan zal het kwaad jou treffen. Integendeel, God is om jou bewogen en Hij schrikt zoals jij, lijdt met jou mee, huilt net als jij. En samen met Hem ga je een gevecht aan met het kwaad of zorg je er voor aan het kwaad niet ten onder te gaan. Van God kun je dan moed, kracht en troost vragen en ook kan van Hem het inzicht worden gekregen, hoe je als lijdende mens op een menselijke en gelovige manier kunt verder leven.

Dit betekent weer, dat niet alles wat ons overkomt wel een zin zal hebben - ook al is die zin voor mensen niet altijd duidelijk - want God is toch de macht die alles overziet en ook het patroon kent dat bij het leven van elk mens hoort? Nee, binnen een visie op God als de Medelijdende is nog al wat ruimte voor het toeval, voor chaos en onzin. ${ }^{17} \mathrm{Bij}$ de opvatting van God als de Almachtige past de gedachte, dat alles wat jou overkomt - in elk geval - van God uit een bepaalde zin heeft. Zelfs het zinloze kwaad heeft vanuit de Almachtige gezien, binnen het patroon dat $\mathrm{Hij}$ voor jouw leven heeft vastgesteld, een diepe zin. Wie God niet als de Almachtige kan ervaren moet dan rekening houden met een grote ruimte voor het toeval, dat in je leven pijn en verdriet kan brengen. Met de hulp van God kan het je dan gelukken in tijden van kwaad rechtop te blijven staan.

Dit heeft tot gevolg, dat je ook niet van God het onmogelijke wilt 
vragen. God kan jouw leven niet opnieuw laten beginnen en alle fouten die je maakt kunnen niet door Hem worden rechtgezet. Voor een dodelijke ziekte, die jou treft, ga je God niet vragen of Hij toch nog een mogelijkheid wil geven, dat de dood je niet wegsleept. God is niet de Almachtige die in jouw situatie even het onmogelijke mogelijk maakt. Dat het kwaad jou treft kan Hij niet voorkomen en dus moet je als gelovige Hem daar ook niet om willen vragen. Het kwaad, dat je overkomt, zal meestal geen zin hebben of zinloos lijken. En alleen op den duur soms na een hele lange tijd kun je er - met Gods hulp - zelf een beetje zin aan geven.

Het bijzonder indrukwekkende en aantrekkelijke van deze visie op God is toch wel het feit, dat nu eindelijk eens over God en het kwaad, dat jou overkomt, wordt nagedacht vanuit jouw gebuktgaan onder het kwaad. Veel te lang en veel te vaak wordt over de verhouding van God en het kwaad gedacht vanuit God en de mensen gebukt onder de slagen van het kwaad moeten dan maar hun weg binnen zo 'n gedachtengang vinden. Vaak light voor een gelovige niet zoveel troost in een redenering die God boven hem selt als de volkomen Andere. Nogal wat opvattingen over God en het kwaad proberen God om zo te zeggen buiten schot te laten - wat Hij doet is toch wel goed - en als je Hem nu niet begrijpt zal dat later misschien wel gebeuren en je moet ook niet vergeten, je kunt als mens God toch nooit helemaal volgen. Pas de gedachte, dat God eerder onmachtig is maar zijn invloed wil aanwenden om, als het kwaad je overrompeld heeft, naast jou te staan om je weer op de been te helpen levert een redenering op die start bij het moment, wanneer het kwaad iets meer van God verwacht? Hoe goed het is te weten, dat God in het bijzonder aanwezig wil zijn wanneer het kwaad heeft toegeslagen, komt niet het moment dat je als gelovige ook eens zoekt, verlangt of hoopt op Gods macht over het kwaad in jouw leven of dat van een ander? Zou God met zijn aanwezigheid in het bijzonder voor de lijdenden niet sterker en machtiger kunnen zijn dan zijn onmacht die in deze opvatting zo sterke nadruk krijgt? Is het mogelijk een opvatting over God, het kwaad en jezelf te ontwikkelen, waarbij van de lijdende mens wordt uitgegaan en Gods macht toch ook het kwaad overstijgt? Bestaat er een macht, waar het kwaad uiteindelijk niet tegenop kan? ${ }^{18}$

Natuurlijk zijn deze vragen niet nieuw, want in elke tijd zoeken zij die proberen zich open te stellen voor de Ander, hoe Hij door hen in hun tijd en binnen hun omstandigheden ervaren kan worden. In onze tijd speelt het grote probleem van twee wereldoorlogen in Westeuropa en de plaats van God hierbij, terwijl over het kwaad dat joden, zigeuners en homosexuelen door medemensen is aangedaan geen mens enige zin kan ontdekken en een gelovige zich afvraagt: waar was God? 
Het kan een grote verrijking voor je geloof in God zijn Hem te ervaren niet als de Almachtige, die alle gruwelen die mensen elkaar kunnen aandoen heeft voorzien en een plaats gegeven binnen zijn plan met deze wereld. Maar vanuit de bijbel wordt ook steeds weer aandacht gevraagd voor een toekomst, waarin toch het kwaad overwonnen zal zijn. In het verlengde van deze bijbelse overweging ontstaat de vraag: is - naast Gods bijzondere hulp voor de lijdende mens - nu ook al iets te merken van zijn macht die machtiger is dan het kwaad? Of anders gevraagd: waar zou je, vanuit Gods Woord, aan kunnen denken als het gaat om een macht die machtiger is dan in het kwaad?

\section{Macht van "het zwakke"}

Van oorsprong heeft het christelijke geloof iets vreemds, iets wat hindert. Als je probeert te geloven, moet zo ' $n$ overtuiging toch enige houvast geven? Maar het lijkt wel of - in het bijzonder door opmerkingen van Paulus - het christelijke geloof weinig stevigheid te bieden heeft.

Hij kan bijvoorbeeld schrijven, dat God heeft besloten hen die geloven te redden door de dwaasheid die wij verkondigen ... want wij verkondigen een gekruisigde Christus. En zo iets is voor joden een ergernis en voor nietjoden een dwaasheid ... want God is in zijn dwaasheid wijzer en in zijn zwakheid sterker dan mensen. 11 Kor 1:21-25).

Geloven in God heeft iets vreemds als centrum, iets wat hindert en, schrijft Paulus, dat vreemde wat zo kan hinderen is nu net dat waar het in jouw geloof om gaat. Gods dwaasheid betekent de hoogste wijsheid en zijn zwakte is sterker dan welk mens ook.

Dus het centrum van het geloof is vaag, onduidelijk en niet erg indrukwekkend. Misschien om die reden hebben vele gelovigen hun hart en mond vol van God als Almachtige die doet wat Hij wil? Schrikken woorden als dwaas en zwak daarom af omdat een gelovige niet in dwaasheid en zwakte wil geloven, en helemaal niet in een dwaze en zwakke God? ${ }^{19}$

Paulus vertelt verder, dat God juist gekozen heeft voor dat wat wij dwaas vinden en in onze ogen als zwak geldt (1 Kor 1:27). Dat betekent ook dat God zich misschien eerder als zwak dan sterk aan mensen presenteert. God laat zich ervaren als Eén die solidair is met wat zwak is en hulp nodig heeft. In het bijzonder laat Hij zich zien in Jezus. Van Jezus kan worden gezegd: aan Hem kun je zien zó is God. Dan gaat het dus om Hem, die als een hulpeloze baby met Kerstmis geboren wordt. Ook hier makkt God zich bekend op een zwakke, tere manier. En zo iets kan enorm hinderen, want diep in je hart wil je als gelovige liever 
een imponerende God kennen en er vanuit gaan dat Hij de allersterkste is, dan te moeten geloven in Ėen die weinig indrukwekkend is en dat dit dan alles zou zijn. Daarnaast wil je graag zeker weten dat Christus onaantastbaar en zegevierend is. En vooral met Pasen zing je dan luid en duidelijk van de onoverwinnelijke macht van Jezus, hoewel Paulus vertelt over de zwakte en dwaasheid van het geloof in Hem.

Trouwens volgens de evangelieschrijvers vormen noch het leven van Jezus noch zijn sterven alleen maar hoogtepunten. Wanneer Jezus sterft vraagt $\mathrm{Hij}$ zelfs aan God waarom die Hem verlaten heeft. De evang elieschrijver Markus beschrijft hoe Jezus niet Gods aanwezigheid maar juist zijn afwezigheid ervaart en, deelt Markus mee, Jezus schreeuwde het uit en stierf (Mark 15:34 en 37). Ook verder bij het sterven van Jezus worden in de bijbel allerlei - althans voor ons gevoel - "zwakke" momenten beschreven. Een "sterke" gebeurtenis als de opstanding wordt door alle vier de evangelieschrijvers heel kort en heel bescheiden weergegeven. Eerst de kerkelijke traditie maakt er met behulp van afbeeldingen en liederen een triomfantelijk gebeuren van, want welke gelovige - en nietgelovige - wil zich niet af en toe heerlijk laten imponeren? En waarom ook niet? Maar hoe kun je, als gelovige, Gods (al)macht op een juiste, bijbelse manier ervaren?

Ligt voor het geloven in onze tijd misschien toch een belangrijk aanknopingspunt in deze "kracht van het zwakke"? Is God nú eerder te ervaren met behulp van deze mogelijkheid van het zwakke, dat jou zo hinderen kan, maar opgevat kan worden als een goddelijke macht?

Als reaktie op God als de Almachtige kun je dus de nadruk op zijn onmachtigheid leggen en daarnaast ontstaat dan als vanzelf de vraag: hoewel God als de onmachtige Mede-lijdende veel kracht en hulp voor een lijdende gelovige kan betekenen, is Hij ook niet nog meer want wat is dan zijn relatie met de toekomst van de mensen en de toekomst van de wereld? In samenhang met het voorafgaande kun je naar de uiteindelijk overwinnende macht en kracht van God zoeken in de sfeer van zwakheid. In de mening dat God de onmachtige Mede-lijdende genoemd kan worden ligt een belangrijke waarheid. Die waarheid luidt: alleen vanuit de lijdende mens zou je een opvatting moeten vormen over God en het lijden of over de macht van God en de macht van het kwaad. Want eerder bij God als de Mede-lijdende dan bij Hem als de Almachtige kan een mens, die lijdt, zich geholpen voelen. Houden we dit uitgangspunt vast, dan kan de vraag worden gesteld: zou het daarnaast dan ook zo kunnen zijn, dat in onze tijd de bijbelteksten over de "zwakke macht" van God je het beste inspireren?

In deze samenhang is een psalmgedicht uit de Tenach van belang. De regels gaan als volgt: "Hoe heerlijk, o God is uw naam op de hele 
aarde. Want $U$, die uw majesteit toont aan de hemel, hebt uit de mond van kinderen, zelfs van de allerkleinsten, $u$ sterkte gevormd om met uw vijanden af te rekenen, om hen tot zwijgen te brengen en aan hun wraakzucht een einde te maken" (PS $8: 1-2)$.

De dichter ziet de (al)macht van God opkomen uit de mond van kinderen en zo kan God sterkte vormen om met zijn vijanden af te rekenen. Gods macht loopt via de mond van kleine kinderen, zegt de dichter. En we herinneren ons dat Paulus het heeft over kracht die voortkomt uit zwakheid. Waarom vertelt de dichter, dat God in het bijzonder werkt via kinderen?

Misschien wel omdat volwasenen steeds weer ontroerd en ontwapend worden door kinderen. Een kind, daar kun je nooit helemaal tegenop en wat kinderen soms zeggen daar word je als volwassene zo maar stil van. Bijvoorbeeld: "God is een rotvent en ik bid niet meer. Gisteren heeft juf gezegd, dat God alles kan en vandaag zegt ze: 'Jullie moeten wat meebrengen voor de kindertjes in Afrika, die hebben honger.' Nou als God alles kan en die kinderen geen eten geeft, is Hij dan niet een rotvent?" - God heeft mensen nodig en die helpen mee - Nou, dat is ook makkelijk: Hij helpen en het ons laten betalen (jongen, 6 jaar oud).

Waarom zeg je niet elke dag je avondgebedje meer? Je zegt alleen maar: dank $U$ voor dit en voor dat, heb je dan niets te vragen aan onze lieve Heer? ... O, jawel, maar je krijgt bijna nooit wat je vraagt. Ik heb wel zes keer gevraagd, wat ik niet gekregen heb. Ik vind dat je maar beter niets kunt vragen en alleen maar bedanken voor wat je wel krijgt. Dan ben je tenminste beleefd, hè mam? En je hebt niet zoveel verdriet omdat het niet komt (meisje, 7 jaar oud).

"Sommige mensen vinden dat ze het leven niet leuk vinden, maar ik vind dat je dat niet zeggen mag, want het is toch helemaal niet prettig voor onze lieve Heer als $\mathrm{Hij}$ dat hoort. Ja en nou zit ik hier te breien en als ik dood ben, kan ik het niet meer doen, dus ik zou het wel kunnen laten, maar je leeft nou eenmaal en dan moet je toch lets doen, dus nou brei ik toch maar door" (meisje, 8 jaar oud). ${ }^{20}$

Van deze voorbeelden gaat een kracht uit, die zo sterk is dat een boze macht daar niet tegenop kan. God bestrijdt het kwaad, nee, Hij overwint het kwaad door de ontwapenende kracht uit de mond van kinderen. Door de ontroering en de glimlach die zulke woorden van kinderen oproepen wil God, om zo te zeggen, het goede in het hart van mensen oproepen en dus het kwaad bestrijden. 
Klinkt dit nu niet te onnozel om waar te zijn? Kun je zulke simpele konklusies uit het Woord van God trekken en daar kracht uit halen voor je geloof in Gods uiteindelijke macht over het kwaad? Houden woorden van kleine kinderen het kwaad tegen? Is dat nu niet veel te naief?

Het woord naïef heeft een latijnse achtergrond en betekent daar zoveel als: aangeboren, natuurlijk, oorspronkelijk, argeloos en kinderlijk. Het woord naïef hangt direkt samen met het latijnse woord voor geboorte en geboren worden. Het franse woord Noël betekent Kerstmis, het feest van de geboorte en in het italiaans en spaans wordt Kerstmis genoemd, Natale en Navidad. Allemaal uitdrukingen die een verbinding hebben met ons woord naïef. ${ }^{21}$

Met Kerstmis ontwikkelt zich dus een goddelijke naïviteit. Een "kinderlijke" daad van God wil iets goeds in beweging zetten door de geboorte van Jezus. Zijn de geboorteverhalen niet ook op te vatten als Gods "zwakke" bemoeienis met mensen? En het is in het bijzonder Jezus, die aandacht vraagt voor het kind. Beter gezegd: in een kultuur waarin de mensen veel minder dan wij gewend zijn het kind op allerlei manieren centraal te stellen, maar juist van het kind verwachten zich in te spannen zo vlug mogelijk het kinderlijke af te leggen, vraagt Jezus, aan wie je kunt zien zó is God, speciale aandacht voor het kind. Hoe is nu de verhouding tussen God en mens binnen de beeldspraak vader en kind?

\section{God en het kind}

Wat in het Tweede Testament heel duidelijk wordt uitgesproken vinden we al aangeduid in het Eerste Testament. We bedoelen de beschrijving van de bijzondere belangstelling, die van Godswege uit kan gaan naar de mens, waarbij het beeld van de gelovige als kind wordt gebruikt.

Zo kan een psalmdichter zeggen: $U$ haalde mij uit de schoot van mijn moeder en legde mij veilig aan haar borst. Aan $U$ werd ik toevertrouwd, vanaf mijn geboorte bent $\mathbf{U}$ mijn God (22:10 en 11). Hieraan aansluitend kan een andere dichter schrijven: $\mathbf{U}$ weefde $\mathbf{m i j}$ in de schoot van mijn moeder, $U$ deed mij ontslaan (139:13). Valt hier nog te denken aan de overweging, dat de gelovige zich kompleet, en wel sinds zijn ontstaan als mens, door God geborgen weet en daarom zo teleurgesteld kan zijn als het kwaad alle ruimte krijgt en God ver weg schijnt, de dichter van psalm 103 doet weer een volgende stap wanneer hij zegt: zoals een vader zich ontfermt over zijn kinderen, ontfermt zich de Heer over wie Hem vereren. Hij kent onze broosheid, $\mathrm{Hij}$ weet dat wij maar stof zijn (13 en 14). Een weer een andere psalm luidt als volgt: Al hebben mijn vader en moeder $\mathrm{mij}$ verlaten, toch zult U, o Heer, bij mij blijven (27:10). ${ }^{22}$ 
De beeldspraak van een al dan niet almachtige God en de gelovige als kind wordt in de profetieën van Jesaja verder uitgewerkt. Hij omschrijft: ... want de Heer heeft zijn volk getroost, $\mathrm{Hij}$ is begaan met zijn arme kinderen. Jerusalem zei: “De Heer heeft mij verlaten, de Heer is mij vergeten." Maar de Heer antwoordde: "Vergeet een vrouw soms het kind aan haar borst, is zij niet begaan met haar bloedeigen kind? En al zou zij haar kind vergeten, Ik vergeet jou nooit!" (49:13-16).

De profeet kan Gods vaderlijke gevoelens omschrijven op de volgende wijze: En God sprak: Zij zijn mijn volk, mijn eigen kinderen, ze zullen Mij niet bedriegen. Zo werd God hun verlosser en in al hun benauwdheden was ook $\mathrm{Hij}$ benauwd ... Hij kwam hen redden in eigen persoon. Liefdevol en mild gestemd bracht $\mathrm{Hij}$ hun verlossing. Hij nam hen op de arm, $\mathrm{Hij}$ droeg hen al die lang vervlogen jaren (63:8 en 9). Van deze vaderlijke trouw en zorg voor het kind lezen we dat God kan zegen: Volk van Israel, ooit heb Ik jullie gezegd: jullie zijn mijn kinderen. Een heerlijk land zal ik jullie geven, mooier dan van enige ander volk! En Ik dacht: zeker zullen zij Mij vader noemen ... (3:19). Deze zorg van God, deze irritatie van de vader tegenover het ongezeggelijke kind en deze onverbrekelijke band tussen God als vader en Ephraim als kind vindt zijn diepste omschrijving in de bekende Ephraimspreuk: (Dit zegt de Heer) ... Ephraim luister, je bent toch mijn lievelingskind, de zoon van wie ik het meeste houd? Telkens weer als Ik je naam noem, denk lk met tederheid aan je, met diepe ontroering en wil je helpen (31:20).

Hoogtepunt binnen deze vader/moeder en kind beeldspraak zijn de innige woorden, die God volgens de profeet Hosea spreekt: Toen Israel nog een kind was heb Ik het liefgekregen, Ik heb hem uit Egypte geroepen en mijn zoon genoemd ... En Ik leerde Israel lopen en nam hem op mijn arm. Maar zij wilden niet erkennen, dat Ik hen verzorgde. Toch leidde lk hen met zachte hand en voerde hen liefdevol mee. Als ouders die hun kind opbeuren om het tegen de wang te drukken, zo was Ik voor hen. Ik boog mij naar hen toe en Ik gaf hun te eten $(11: 1-4) .^{23}$

Het blijkt dat God niet los kan komen van zijn volk, zijn kind! Zijn volk ontroert Hem zoals een kind zijn vader en moeder ontroeren kan. Vader en moeder komen in beweging, willen uiting geven aan die band, die er is en blijft tussen ouders en kind. Zo kan de profeet Jesaja God sprekend invoeren met de woorden: Zo zegt de Heer: Zoals men water naar een stad leidt, het water van een volle beek, zo leid Ik de vrede naar Jeruzalem, naar Sion de rijkdom van de volken: dan zul je zuigen en je zult op de heup worden gedragen en op de 
knieën gekoesterd. Zoals een moeder troost, zo zal Ik je troosten (66:12 en 13).

Dichters als de auteurs van psalmen en profeten met hun poëtische aanleg kunnen de verhouding tussen God en zijn volk omschrijven als de onbreekbare band tussen vader en moeder met hun kind. Als kind is het volk Israel zo onweerstaanbaar aantrekkelijk voor God, als kind heeft Israel - om zo te zeggen - macht over God en God erkent deze "kinderlijke" invloed.

Vooral in het Nieuwe Testament wordt verteld hoe belangrijk het kind kan zijn. Zo belangrijk, dat Jezus van mening is dat volwassenen moeten omkeren ( = zich bekeren) en worden als kinderen. Volgens Hem is het kind-zijn niet maar een moment op de weg naar volwassenheid of een fase die je moet achterlaten als iets dat voorbijgaat. Nee, de volwassene mist iets wat het kind heeft. Arme volwassene.

In de beschrijvingen van Jezus' leven gaat het om het kind op zich en daarnaast om de heilstijd, die aanbreekt met de geboorte van het kind Jezus. Het kind blijft in Jezus' opvatting centraal wanneer Hij bijvoorbeeld zegt: voor hen is het koninkrijk van God (Mat 19:14). En Hij gaat heel ver op deze weg als we lezen: Ik verzeker jullie: wie het koninkrijk van God niet aanvaardt, zoals een kind aanvaardt, zal er zeker niet binnenkomen (Mark 10:15). ${ }^{24}$

Een andere keer roept Jezus een kind, duwt het een kring volwassenen binnen met de opmerking: Ik verzeker jullie, volwassenen, het hemels koninkrijk kom je alleen binnen als je van gezindheid verandert en wordt als kinderen. De belangrijkste in het hemelse koninkrijk is dus hij die zich zo onbelangrijk vindt als dit kind (Mat 18:4).

Jezus blijft wijzen naar dit kind en voegt nog toe: Wie in mijn naam zo 'n kind ontvangt, zo iemand ontvangt Mij (Mark 9:37). Duidelijker kan het niet: Jezus en het kind horen bij elkaar en hebben iets van elkaar. Jezus de volwassene heeft iets wezenlijks van zijn kind-zijn vastgehouden. Door naar een kind te wijzen binnen een kring van volwassenen laat Hij merken: het feit, dat lk kind ben geweest is van blijvende betekenis voor iemand die probeert in Mij te geloven. ${ }^{25}$

Een oude joodse wetsgeleerde als Nikodemus raakt verward wanneer Jezus tegen hem zegt: niemand kan zomaar het koninkrijk van God zien; eerst moet hij opnieuw geboren worden. Maar, vraagt Nikodemus dan, hoe kan iemand die al volwassen en ouder is opnieuw geboren worden? Moet hij dan terug in de buik van zijn moeder? En Jezus reageert met de woorden: niemand kan het koninkrijk van God binnenkomen als hij niet geboren wordt uit water en Geest (Joh 3:3-6). 
Uit het verdere verhaal blijkt nu, dat die uitdrukking "geboren uit water en Geest" een andere omschrijving is voor "geboren worden uit

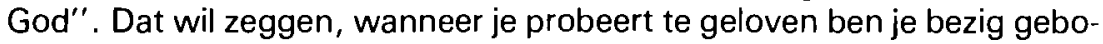
ren te worden uit God. Wie gaat geloven wordt weer kind en God is zijn Vader. Zoals Jezus het kind van zijn Vader is, net zó zul je als gelovige kind van Jezus' Vader worden. ${ }^{26}$ Van deze Vader zul je proberen te houden met je hele hart, ziel, alle kracht en je komplete verstand. Zowel Mattheus (22:37), als Markus (12:30) als Lukas (10:27) geven de woorden van Jezus op deze manier weer. Het gaat hier om een citaat uit de Tora (Deut 6:5 en Lev 19:18) ... heb de Heer je God lief met je hele hart, je hele ziel en met alle kracht ..., maar volgens de evangelisten voegt Jezus aan dit citaat toe de woorden en je komplete verstand. Dit wil zeggen, dat kind worden niet betekent onnozel worden. Integendeel, door de kritiek heen, via de weg van de twijfel - dus met behulp van "volwassen" ervaringen - kom je tot een kritische kinderlijkheid, een gezond-kritsche naïviteit. ${ }^{27}$

Dit alles betekent, dat jouw manier van geloven en de manier waarop een kind leeft met elkaar te vergelijken zijn, volgens Jezus. Aan de manier waarop een kind leeft kun je zien, hoe jij als gelovige zou moeten leven. De kracht van je geloof ligt in het zwakke en kinderlijke. Wat zijn enkele kenmerken van de manier waarop een kind leeft? ${ }^{28}$

Een kind heeft een verregaand vertrouwen in volwassenen, die voor hem vader en moeder zijn. Een kind doet dit niet op grond van nauwkeurig overwegen en berekenen, maar het weet en voelt zich bij vader en moeder geborgen.

Een kind maakt zich niet zoveel zorgen over de dag van morgen. Het gaat voor een kind om het moment en straks is van weinig of geen belang. Gefascineerd is het kind door het nú.

Ook valt op dat een kind met diepe ernst speelt en spelenderwijs de meest ernstige vragen stellen kan. Bij een kind is het serieus bezig zijn spel en spel serieus bezig zijn.

Een kind kent nog niet het verschil in geslacht. Hoewel het kind thuis de relatie van liefde tussen vader en moeder merkt, blijft het er onbekommerd bij en al naar gelang de ruimte binnen het gezin, praat het kind over sexuele zaken open en bloot zonder te blozen.

Een klein kind wil zich laten troosten als het verdriet heeft, want verdriet wordt niet gekoesterd. Zonder gevoel van schaamte zoekt hij troost bij anderen, die hem koesteren. De pijn en het lijden zijn ervaringen die door middel van huilen en zich laten troosten verwerkt worden.

Onderzoek toont aan, hoe kleine kinderen - wanneer ze ernstig ziek zijn - vaak weten dat ze sterven zullen. En of ze gelovig opgevoed zijn of niet ze spreken over hun sterven in religieuze denkpatronen. De 
kinderen duiden aan, hoe ze op weg zijn naar een "land waar je altijd spelen mag" of ze vertellen 's nachts het gevoel te hebben dat iets of iemand bij hen is om hen te helpen. Afscheid nemen van hun ouders vinden ze erg, terwijl het sterven zelf voor hen doorgaans de overstap in een ander, aantrekkelijk leven betekent. ${ }^{29}$

Tenslotte: in een gezin, waarin bijvoorbeeld de vader is overleden kan het kleine kind vragen: komt pappa weer gauw thuis? En als een ontkennend antwoord komt kan de reaktie volgen: nou dan ga ik maar eens op zoek naar een nieuwe pappa. Ook gebeurt het, dat kinderen heel bewust aan een volwassene vragen: zou u mijn nieuwe pappa willen zijn? Wat kom je verder met deze kindermanieren? En wat is de verbinding met jouw manier van geloven in God en de macht over het kwaad? Als Jezus zegt dat iemand, die het koninkrijk van God niet aanvaardt zoals een kind aanvaardt, daar niet zal binnenkomen bedoelt Hij toch, dat binnen de sfeer van het geloof een manier van leven moet gelden zoals bij kinderen. En is niet alles bij kinderen er op aangelegd om verder te komen, verder te leven en zich te willen handhaven, hoe ook? Dat leven vol vertrouwen in een ander, dat leven vol concentratie op het moment, die vermenging van spel en realiteit, die onbevangenheid tegenover het sexuele, het verlangen om je te laten troosten, het zekere weten dat na de dood een ander leven komt en de vaste wil om een gebroken situatie weer heel te krijgen ... Zou dat "een macht ten goede" kunnen zijn waar op den duur het kwaad niet tegenop kan? Zijn deze naieve, natuurlijke en tere levensuitingen nu juist de onoverwinnelijke levenskracht, die God in mensen legt om tegen het kwaad toch stand te houden? Ligt dus je kracht om te leven binnen de jou omvattende, tere kracht van God?

Omdat Jezus zelf zo opvallend vaak herinnert aan een kind als $\mathrm{Hij}$ het heeft over de toegang tot het koninkrijk van God komt de gedachte naar voren, dat de macht van dat koninkrijk zou kunnen liggen in een geloofsfeer, die Jezus vergelijkt met de levensfeer van kinderen die God als hun vader en moeder hebben. Om wat voor soort macht zou het dan gaan?

\section{Macht van de bevrijdende vrijheid}

Wanneer je God als de Almachtige wilt ervaren raak je met zo 'n opvatting over Hem in de problemen. Wanneer je God als de Onmachtige en Mede-lijdende wilt opvatten raak je verstrikt in andere problemen. Als je God ervaart als de Almachtige heb je vaak te kampen met een enorme afstand tussen de Almachtige en jezelf, want $\mathrm{Hij}$ weet alles, heeft alles al vooruitgezien en jouw leven helemaal uitgestippeld. Als God mede-lijdt met hen die getroffen zijn door het kwaad, bewogen is om de slachtof- 
fers en lijdende mensen helpt om te vechten tegen het kwaad, lijkt het wel of Hij niet een macht boven het kwaad is en, kun je je dan afvragen, komt ooit nog eens "een nieuwe hemel en een nieuwe aarde", waarop recht wordt gedaan aan ieder mens en de komplete verdere schepping? Hebben die profetische beloften over een God, die "alle tranen van de ogen zal afwissen" - omdat dood, rouw en geklaag niet meer bestaan - nog wel een konkrete bedoeling? Hoever reikt Gods macht tegen het kwaad en kun je als gelovige iets ervaren van die "verte"? ${ }^{30}$

Misschien is dat mogelijk wanneer je nadenkt over de manier, waarop het kwaad funktioneert. Dat wil zeggen: is een bepaalde lijn te ontdekken in de vele wegen die het kwaad bewandelt om het goede in zijn greep te krijgen?

Het kwaad is een enorme macht, die zich opdringt en niet over het hoofd is te zien. Het goede is een enorme macht, die zich opdringt en niet over het hoofd is te zien. Maar er is een verschil. Het kwaad is een macht, die afhankelijk maakt en afhankelijk houdt. En ook de vrijheid die door het kwaad wordt aangeprezen blijkt op den duur telkens weer een gebonden, schijnbare vrijheid te zijn, het soort vrijheid waaraan een mens kapot kan gaan.

Zou het niet zo kunnen zijn, dat de macht van het goede nooit een alles neerdrukkende macht is, waaraan je blijft gebonden als je eenmaal in de greep van die macht vast komt te zitten? Zou het kenmerk van de macht van het goede niet kunnen zijn, dat Gods macht jou niet neerdrukt en afhankelijk maakt, maar je juist vrijmaakt?

Wie probeert te geloven heeft een beweeglijke driehoeksverhouding. Er ontstaat dan een beweeglijk relatie met de Ander, de ander en jezelf. Deze beweging wordt beinvloed door je eigen levenservaring en de levensfase waarin je verkeert en tot stilstand komt die beweging nooit. Steeds weer gaat het binnen deze relatie om het je openstellen voor God, de ander en jezelf. Ook hier betekent deze verhouding een bevrijding eerder dan een last. God en de ander houden jou niet in hun greep, nee er blijft dat onophoudelijke heen-en-weer gaan, dat niet 'gebonden' kan worden.

Om werkelijk in vrijheid te leven heeft Christus ons vrijgemaakt, schrijft Paulus (Gal 5:1). Is die macht van de vrijheid niet uiteindelijk sterker dan de macht van de onvrijheid? De binding, de verslaving en de verstrengeling die ontstaan binnen het machtsgebied van het kwaad staan haaks op de ongebondenheid, vrijheid en helderheid binnen het machtsgebied van God. Blijkt Gods macht niet steeds daar, waar het geloof in Hem mensen vanuit vrijheid laat leven? En blijkt ook niet telkens weer, dat mens-zijn en vrij-zijn bij elkaar horen? Verliest het kwaad niet almeer terrein als mensen proberen vanuit de macht van de "bevrijdende 
vrijheid" te leven en zou de zogenaamde almacht van God niet kunnen betekenen, dat de bevrijdende vrijheid het eens - hoe ook - zal winnen?

Zo ' $n$ onoverwinnelijke macht is niet gemakkelijk zichtbaar te krijgen om indruk te maken. Het indrukwekkende en duidelijk zichtbare van het kwaad wordt door het bijna naïeve en simpele van de invloed van Gods macht eerder in stilte ondergraven. Dus iemand die probeert te geloven zal niet zo gauw op dezelfde manier als het kwaad zich breed maakt, een aktie tegen het kwaad onderneem. In dit verband adviseert Paulus dan ook vergeld geen kwaad met kwaad (Rom 12:17). Dit zou dan kunnen betekenen, dat hij aanraadt niet op dezelfde manier als het kwaad werkt dat kwaad ook te lijf te gaan.

Is nu alles duidelijk en overtuigend? Nee, het schrijven over Gods bevrijdende vrijheid in plaats van zijn almacht is even theoretisch als in God de Almachtige zien, die alles heeft voorzien en voorbeschikt, of de mede-lijdende Onmachtige, die bewogen is om de lijdende mens. Het voordeel van de opvatting, dat Gods almacht zijn bevrijdende vrijheid betekent ligt in het afzien van de mening over een almachtige God, die een gelovige in bedwang houdt en bijna onmondig onnozel maakt, of een onmachtige God, die wel bewogen is maar niet tegen het kwaad op kan. Wie hierdoor als gelovige eerder geirriteerd dan getroost en meer gehinderd dan geholpen wordt zou misschien vanuit Gods bevrijdende vrijheid mogelijkheden en inspiratie kunnen vinden zich staande te houden in een leven dat vaak van kwaad vergeven schijnt te zijn.

Gods naam Ik ben aanwezig, op mijn manier laat merken, dat alles wat je zegt over zijn macht, ook al is het nog zo bijbels verantwoord, in wezen gestotter en gestamel is omdat Gods onoverwinnelijke aanwezigheid wel ervaren kan worden maar nooit in woorden gevangen. Voorkomen kan wel worden, dat bepaalde opvattingen over Gods macht of onmacht tegenover het kwaad een last worden voor een bevrijdende en ontspannen manier van geloven. Maar het blijft wel gemakkelijker te omschrijven hoe je beter niet in Gods almacht kunt geloven dan hoe het precies wel zou moeten.

Is Jezus zelf ook niet een voorbeeld van iemand, die het kwaad te lijf gaat op een bijna simpele manier? Zowel zijn wonderen, zijn genezingen als zijn woorden overtuigden de mensen van zijn tijd nauwelijks, dat Hij Gods goede macht vertegenwoordigde en gekomen was om mensen te redden en te bevrijden. Zo gauw Hij de mensen teveel hinderde zorgden ze er voor Hem kwijt te raken. In het moment van sterven vraagt $\mathrm{Hij}$ aan God waarom die Hem verlaten heeft. ${ }^{31}$

Als het kwaad mensen die het goed willen doen treft, is God dan afwezig? Zoals Jezus tenonder ging gaan wellicht velen te gronde, die 
het goed willen doen. Maar zoals Jezus door God werd vastgehouden houdt God anderen vast, hoewel ze denken te gronde te gaan. Juist voor hen, die het gewoon goed willen doen, is de dreiging van het kwaad steeds aanwezig en het is $\mathrm{Hij}$, die hoort, ziet en weet hoe de macht van het kwaad mensen laat lijden en daarom zet $\mathrm{Hij}$ zich in beweging naar mensen toe die door kwaad zijn getroffen. Hij voorkomt niet, dat het kwaad toehapt, maar $\mathrm{Hij}$ inspireert om die krachten en gedachten te mobiliseren waar het kwaad niet blijvend tegenop kan. En zo vinden steeds weer, met Gods hulp, grotere en kleinere overwinningen plaats.

En komt het ooit nog eens goed? Wint Gods goede macht het nog eens van de macht van het kwaad? Wie probeert te geloven in God houdt rekening met het koninkrijk van Hem en heeft met vallen en opstaan ook deel aan dat koninkrijk. Over dat deelhebben zegt Jezus: wie het koninkrijk van God niet aanvaardt, zoals een kind aanvaardt, zal er zeker niet binnen komen (Mark 10:15).

Is één van de kenmerken van een kind niet een zeker naïef soort vertrouwen samen met een gevoel van zich geborgen te weten bij vaderen moederfiguren? Is dat het, wat geloven in feite inhoudt: een oervertrouwen (in de goede afloop) en het gelukkige gevoel van - ondanks alles - geborgen zijn?

In deze samenhang passen ook woorden van Paulus uit één van zijn brieven: ... beperkt is ons kennen en beperkt is ons profeteren. Maar wanneer de volmaakte toestand komt, zal wat beperkt is verdwijnen. Toen ik een kind was, sprak ik als een kind, dacht ik als een kind, redeneerde ik als een kind; eenmaal volwassen geworden, legde ik af wat kinderlijk was. Nu zien wij nog indirekt, met behulp van een spiegel, maar eens staan wij oog in oog. $\mathrm{Nu}$ is mijn kennis beperkt, maar eens zal ik kennen zoals God mij kent (1 Kor 13:9-12).

Even heb je de indruk dat het Paulus gaat om: eenmaal volwassen geworden, legde ik af wat kinderlijk was. Paulus zou bedoelen, dat een gelovige gauw volwassen moet worden en op een volwassen manier moet reageren op de problemen van het leven. Maar Paulus' woorden verspringen. Eerst gaat het om kind-zijn en daarna om het volwassen worden, maar dan komt een ommezwaai: nu is alles nog beperkt maar later wordt het kompleet. Eerst gaat het om "toen ik een kind was" en "nu ik volwassen ben geworden", maar dan komt die ommezwaai: nu leef je in de onvolkomen "kinderlijke fase" en straks bij God ervaar je de "volwassen sfeer". Nu in dit leven geloof je nog inkompleet, zijn alle dingen vaag en niet helemaal duidelijk maar eens zul je je kompleet voelen en helder kunnen zien zodat alles duidelijk wordt. ${ }^{32}$

Paulus wil dus zeggen: geen enkele gelovige is 'volwassen' in het 
geloof. Je ziet nog maar in een spiegel met al zijn vertekeningen van het werkelijke beeld. Geloven in dit leven gaat zoals een kind leert lopen: met vallen en opstaan. Maar een andere manier van geloven is er niet en volgens Jezus - ligt in die beperkte, maar wel kritische, kinderlijke manier van geloven in dit leven juist de kracht van het geloof. Via die invalshoek wil God zijn uiteindelijke macht over het kwaad voor gelovigen en nietgelovigen kenbaar en ervaarbaar maken.

\section{AANTEKENINGEN}

1. Heel in het kort hebben we nu beschreven wat van Peursen de ontologische fase van onze kultuur noemt. Hij onderscheidt drie fasen binnen de westerse kultuur: de mythische, de ontologische en de functionele. Vgl. C A van Peursen, Cultuur in stroomversnelling, 1982c, 80-111.

In de mythische fase probeert de mens zich niet tegenover de natuur als subjekt tegenover objekt op te stellen. De mens blijft deel van de natuur en reflekteert nog niet over zichzelf en zijn verhouding tot de natuur. Bij de mythe-vorming gaat het om de beschrijving van ervaringen met de natuur opgedaan. De mythevormende mens voelt zich door de werkelijkheid om hen heen geobsedeerd. Hij beschrijft de geschiedenis in een herhalende, stationaire vorm. Een negatiewe kant van deze beleving van de werkelijkheid is dan de magie, met behulp waarmee goden en mensen kunnen gemanipuleerd worden. In de ontologische fase is de mens bevrijd uit de 'ban' van de mythe en stelt hij zich als subjekt op tegenover de natuur als objekt. De mens neemt dus distantie aan tegenover de te onderzoeken werkelijkheid. Hij omschrijft, definieert (= omgrenst) en objektiveert. Hier loopt hij overigens het gevaar via zijn definities het te onderzoeken objekt zo te isoleren, dat deze uit de oorspronkelijke samenhang van alle dingen met elkaar te verdwijnen dreigt. In de funktionele kultuurfase ziet de mens zich niet meer geisoleerd als subjekt tegenover objekt, maar hij is existentieel bij alles betrokken. Hij probeert mede eigen ervaring in het spel te brengen in die zin, dat de vraag wordt gesteld: wat voor nut, wat voor funktie hebben allerlei objektieve, vanuit de traditie overgeleverde waarheden? Het subjekt heeft in het verleden toch steeds weer de definities over het objekt persoonlijk gekleurd? is het wel mogelijk via definities de woorden van God zuiver weer te geven? Hangt alles in Gods Woord niet zozeer met elkaar samen, dat een definitie - dus het vaststellen van grenzen - niet goed mogelijk is omdat de bijbel eerder een weefsel van gedachten en ervaringen is dan een verzameling van uitspraken over God die door de onderzoeker moet worden gerangschikt en is het daarom niet beter.bij de konkrete situatie te beginnen dan bij de algemene regel?

2. Zijlstra "vertaalt" deze drie fasen naar de sfeer van het geloof; vgl. W Zijlstra, "'Geloven' in een functioneel tijdperk" in: Doen wat er te doen staat (Feestbundel Lindijer) Den Haag 1984, 37-46.

3. C T R Hayward "The Holy Name of the God of Moses and the Prologue of St John's Gospel," NTS 25 (1978), 16-24; vgl. ook S Terrien, The Elusive Presence, Toward a new biblical theology, San Francisco 109-119.

4. C Houtman, Exodus (Commentaar op het Oude Testament) Kampen 1986, $102-104$.

5. S Terrien, The Elusive Presence, passim.

6. Ex. r.3.6 vgl. b.v. C G Monterfiore-H. Loewe, A rabbinic anthology, New York 1974 , 5-6; Elke morgen nieuw, Inleiding tot de joodse gedachtenwereld aan de hand van 
het Achttiengebed, B Folkertsma-Stichting voor Talmudica 1978, $206-207$.

7. Nieuwere uitgaven binnen dit gebied behandelen niet of nauwelijks de door ons onderzochte problematiek vgl. O H Pesch, "Theologische Uberlegungen zur 'Vorsehung Gottes' im Blick auf gegenwärtige natur- und humanwissenschaftliche Erkenntnisse", in: F Böckle, Christlicher Glaube in moderner Gese/lschaft. 4. Freiburg 1982, 74-119; W Breuning. "Gott/Trinität", in: P Eichert, Neues Handbuch theologischer Grundbegriffe, 2, München 1984, 123-126. "Vorsehung/Geschichtstheologie", in: P Eichert, idem, 4, München, 1985, 252-262.

8. Ter afsluiting van een oudtestamentische reeks teksten gebruikt Paulus eenmaal deze uitdrukking (2 Kor 6:18). In de Johannesapokalypse gaat het om 1:8; 4:8; $11: 17 ; 15: 3 ; 16: 7$ en $14 ; 19: 6$ en $15 ; 21: 22$. De achtergrond van deze passages ligt toch in de bedoeling Gods almacht te beschrijven.

9. Vgl. A S van der Woude, s.v. saba in: THAT, II, 498-507; H Langkammer, s.v. pantokrator in: EWNT, III, 25-27.

10. Ruth, een vertaling om voor te lezen. NBG Amsterdam KB Boxtel 1974; zie b.v. voor verdere achtergronden van de godsnaam Sjaddaj het uitvoerige artikel van $W$ Weippert, s.v. Saddaj in: THAT, II, $873-881$.

11. J A Sanders, "First Testament and Second", BiThBull. 17 (1987), 47-49.

12. J Lust, Ezéchiel, XX, 4-26. "Une parodie de l'histoire religieuse d'Israel", EThL 43 (1967), 488-527; W Zimmerli, Ezechie/ I, Neukirchen-Vluyn 1969, 432-459; H Gese, Ezechie/ 20, 25f. und die Erstgeburtsopfer (Festschr. W Zimmerli) Göttingen 1977, 140-151; B Lang, Ezechiel. Der Prophet und das Buch, 1981; J Blenkinsopp. A History of prophecy in /srael. From the settlement in the land to the Hellenistic Period, Philadelphia 1983, 193-207; M Greenberg, Ezekiel, 1-20, Garden City, New York, 1983, 360-388.

13. Over Job zijn belangrijke gedachten ontwikkeld o.a. door $\mathbf{P}$ Drijvers-P Hawinkels, Job (Bilthoven) 19712; A de Wilde, Das Buch Hiob, Leiden 1981 en A van Selms, Job / en II. Nijkerk 1982/1983. Een goede weergave van het moderne onderzoek (met veel literatuur) geeft J Ebach in: TRE, s.v. Hiob/Hiobbuch. lets ouder, maar nog steeds van belang is H.P Müller, Das Hiobproblem. Seine Stellung und Entstehung im A/ten Orient und Alten Testament, Darmstadt 1978. Het tijdschrift Concilium wijdde een heel nummber aan Job onder de titel Job en het swijgen van God, Conc (N)9 (1983), vooral van belang zijn o.a. CWestermann, De twee gezichten van Job, 19-28 en ook J-C Sagne, Jezus' uitroep aan het kruis, 59-67.

14. Zie b.v. het hoofdstuk "Der Mensch vor Gott" bij H.J Kraus, Theologie der Psalmen, Neukirchen-Vluyn 1979, 171-22.

15. A van der Born, Wijsheid van Jezus Sirach, Roermond 1968, 195-198; J G Snaith, Ecclesiasticus, Cambridge 1974, 192- 196 en verder P C Beentjes, “Recent Publications on the Wisdom of Jesus ben Sira (Ecclesiasticus)," Bijdragen 43 (1982). $188-198$ en wat over Jesus Sirach staat bij M Gilbert, Wisdom Literature in: $M$ Stone (ed.) Jewish writings of the Second Temple Period, Assen 1984, 290-298.

16. Het belang van het vooral in Amerika en Nederland zeer bekende boek van Harold Kushner, Als 't kwaad goede mensen treft, Baarn 1983 ligt toch wel daar, dat deze rabbijn probeert vanuit het slachtolfer na te denken over God en het kwaad en niet 'verder' argumenteert dan het slachtolfer van het kwaad verwerken kan. Zie in dit verband ook een vraaggesprek op de belgische televisie met een zwaargehandicapte priester naar aanleiding van dit boek van Kushner, Als ' $t$ kwaad goede mensen treft, in: KTRC-Programmateksten 6/7 (juni/juli 1984), 39-45.

17. $\mathrm{Vgl}$. het onder 16. genoemde boek van Kushner en de opmerkingen in het genoemde televisieinterview

18. Vgl. b.v. A $\bar{R}$ van de Walle, Tot het aanbreken van de dageraad, Gevecht op leven 
en dood, Averbode 1981.

19. Voor deze al bij Luther aanwezige gedachten vgl. H A Oberman, "De aangevochten God. De betekenis van de reformatie voor onze tijd". Rondom het Woord 21 (1979), $30-34$.

20. Overgenomen uit $J$ L Klink, Geloven met kinderen, Baarn 1976, 56, 115, 123.

21. Vgl. b.v. G van Leeuwen, "Naiviteit als theologische categorie", Rondom het Woord 24 (1982), $51-55$.

22. Voor meer uitleg vgl. A Wünsche, Midraschim Tehillim, 1/II, Hildesheim 1967 (repr. Nachdruck 1892) en o.a. J Ridderbos, De Psalmen, I en II, Kampen 1955/1958; J P $M$ van der Ploeg. Psalmen, I en II Roermond 1971/1974; H-J Kraus, Psalmen, I en II, Neukirchen-Vluyn 1978.5

23. Voor deze vertaling en de tekstkritische kwesties, die hiermee samenhangen vgl H Donner, Israel unter den Völkern, Die Stellung der Klassischen Propheten des 8. Jahrhunderts v. Chr. zur Aussenpolitik der Könige von /srael und Juda, Leiden 1964, 85-86; J Volmer, Geschichtliche Rückblicke und Motive in der Prophetie des Amos, Hosea und Jesaja, Berlin 1971, 57-60; I Willi-Plein, Vorformen der Schriftexegese innerhalb des Alten Testaments, Berlin 1971, 195-203; vgl. verder nog $\mathrm{E}$ Zenger, "Durch Menschen zog ich sie ..." (Hos. 11,4). Beobachtungen zum Verständnis des prophetischen Amtes im Hosseabuch, in L Ruppert e.a., Künder des Wortes (feestbundel J Schreiner), Würzburg 1982, 183-201 en ook A Deissler, Das "Echo" der Hosea-Verkündigung im Jeremiabuch, in: idem, 61-75.

24. Vgl. Mat 5:9, zalig de armen van geest, zij zullen kinderen Gods worden genoemd; Mat 5:45 (Luk 6:35) opdat gij kinderen moogt zijn van uw hemelse Vader (van de Allerhoogstel; waarschijnlijk zijn Mat 18:2,3,4 en 5 kinderen als beeldspraak bedoeld en 19:14 letterlijk, terwijl bij Markus (9:36 en 37) het ook eerst om beeldspraak gaat, daarna (10:14) letterlijk bedoeld is en daarna weer figuurlijk (10:15), vgl. ook Luk 18:15, 16 en 17. Het is duidelijk, dat door de evangelisten met groot gemak van letterlijk naar figuurlijk wordt overgegaan en de grenzen niet steeds helder te trekken zijn.

25. Zie in deze samenhang Luk 9:47 en 48; te denken valt ook aan Luk 10:21 (= Mat $11: 35$ l lk dank $U$, Vader, Heer van hemel en aarde, dat $U$ deze dingen voor wijzen en verstandigen hebt verborgen, maar aan kinderen hebt geopenbaard; vgl. ook Mat 21:16 ( = Ps 8:3). Mogelijk speelt de zogenoemde Nathansbelofte (2 Sam 7:14) ook een rol, zie 2 Kor 6:18.

26. Heel duidelijk Rom 8:6, 15,16,17 en 21; verder is er sprake van kinderen der belofte in Gal 4:19,25,27,28 en 31; vgl. ook nog Eph 5:1.

27. Over deze zogenoemde "tweede naiviteit" - een uitdrukking van Paul Ricoeur - is 0.a. geschreven door A Vergote, Het huis is nooit af, Antwerpen/Utrecht 1974, $76-845$ en het onder 20 genoemde artikel van $G$ van Leeuwen; voor een uitvoerige kritische bespreking van dit begrip O Jager, Geloven wordt onwennig. Naar een tweede primitiviteit? Ten Have 1987.

28. Vgl. b.v. J Splett, "Kindsein als Offenheit. Ein Beitrag christlicher Phänomenologie", ThPh 60 (1985), 88-97. In deze samenhang moet ook worden genoemd P Schwarzenau, Das göttliche Kind, Der Mrthos vom Neubeginn, Stuttgart 1994.

29. Over kleine kinderen die ernstig ziek zijn en kinderen die weten te zullen sterven vgl. G M Furth, The use of drawings made at significant times in one's life, in: E KüblerRoss, Living with death and dying, New York 1981, 63-94; van nederlands zijde is van belang P J C Stolp, "Pastoraat aan ernstig zieke kinderen," MGV 12 (1984), 1308-1319. Na dit artikel schreef hij nog een boek met de titel A/s de dood vroeg komdt, omgaan met ernstig zieke kinderen, Kampen 1986. Uitgaande van zijn 
onderzoek bij deze kinderen en zijn konklusies, schreef hij ook een korte roman: Hans Stolp, De gouden vogel, dagboek van een stervende jongen, Rotterdam 1987 en al eerder schreef E Kübler-Ross een vergelijkbaar boekje, Remember the Secret, Berkeley 1982.

30. Vgl. H Häring, "Het kwaad als vraag naar Gods macht en machteloosheid," TTh 6 (1986), 351-372. Vgl. verder J Moltmann, "Die atomare Katastrophe: wo bleibt Gott?" Evang. Theol. 47 (1987), 50-60 en U Ruh, "Wo und wie handelt Gott?" HerKorr 41 (1987), 81 -84 en eerder zijn verschenen A van de Beek, Waarom? Over lijden, schuld en God, Nijkerk 1984; H Häring, Das Problem des Bösen in der Theologie, Darmstadt WBG 1985; Nogmaals: Waarom? Nijkerk 1986.

31. Over Jezus' zogenoemde "Lebenskurve ... als Zeichen der Ohnmacht", vgl. G Ebeling, Dogmatik des christlichen Glaubens, II, Tübingen 1982², 471-473.

32. O Jager, Geloven wordt onwennig, 176; $\mathrm{H}$ Berkhof, Bijbeloverdenkingen, Nijkerk $1986,121-125$. 